3. Музыка О.А. Линейная (классическая) и нелинейная (постнеклассическая) концепции социальноисторического процесса: сравнительный анализ. Фундаментальные исследования. 2012. № 11-1. С. 192-196.

4. Попов В.В., Солодухин О.А. К логической проблеме изменений во времени// Философские науки. 1991. № 5. С. 174 .

5. Попов В.В. Современное предпринимательство: социально-экономическое измерение. Емельянов С.Г., Голик Н.И., Новикова И.В., Чиркова М.Б., Федосов П.Е., Золоторев В.Н., Попов В.В., Овчинникова Т.И., Клойзнер В.Д., Девяткин Г.Т., Вавулин Д.А., Тимошенко О.А., Варламова Т.П., Лахнова Т.В., Могилевская Г.И., Лаврентьева И.В., Великая Е.Г., Литвинова А.В., Семенов В.А., Исупова О.А. и др. Воронеж, 2003. Книга 3.

\title{
Токарев Д.А. \\ Гедонистический подход в рассмотрении страдания английскими философами Нового времени
}

Омский институт водного транспорта - филиал ФГБОУ ВО «СГУВТ»

(Россия, Омск)

doi: 10.18411/lj-05-2021-289

\section{Аннотация}

В статье рассматривается гедонистический вариант атрибутивной модели страдания на основе философских взглядов Джона Локка, Дэвида Юма и Иеремии Бентама. Проанализированы различные источники XVII - XVIII веков, литература об английских философах Нового времени, в которых, так или иначе, затрагивается проблема страдания и гедонистический вариант его преодоления. Подчеркивается тесная связь страдания и удовольствия с рефлексией человека. Страдание определяется в рациональном контексте, но с этическим следованием от религиозного мироощущения к новым тенденциям светского характера.

Ключевые слова: страдание, гедонизм, атрибут, Локк, Юм, Бентам, рефлексия, рациональный и этический подход.

\section{Abstract}

The article considers a hedonistic version of the attributive model of suffering based on the philosophical views of John Locke, David Hume, and Jeremiah Bentham. The article analyzes various sources of the XVII - XIX centuries, the literature about the English philosophers of the New Time, which, in one way or another, touches on the problem of suffering and the hedonistic version of its overcoming. The close connection of pain and pleasure with human reflection is emphasized. Suffering is defined in a rational context, but with an ethical following from a religious worldview to new trends of a secular nature.

Keywords: suffering, hedonism, attribute, Locke, Hume, Bentham, reflection, rational and ethical approach.

Новая эпоха, связанная, прежде всего, с бурным развитием наук, образования, культуры, а также с началом индустриализации всех сторон жизни европейцев и жителей Нового света, принесла и новый подход к рассмотрению страдания и его проявлений в нравственных и религиозных представлениях многих философов в различных странах. Были предприняты попытки еще большего рационального объяснения страдания. В целом приоритетность гедонистического подхода сохранилась и в работах авторов новой эпохи. Меняются аргументы, некоторые установки, но суть подхода к причинам, проявлениям и преодолению страдания остается. Удовольствие и страдание по-прежнему рассматриваются в комплексе. Интересна позиция на страдание, его проявления и возможности преодоления английских философов XVII XIX веков Джона Локка, Дэвида Юма, Иеремии Бентама. Период Нового времени усиливает рационалистические принципы философского анализа, но при этом в нём 
много этических рассуждений, связанных и с религиозными представлениями и со светскими нововведениями. Гедонизм Нового времени имеет более диалектическую линию и позволяет определить страдание как основу жизни человека, а удовольствие как следствие влиятельности страдания, как возможность некоторого отдыха от страдания.

Локк и Юм сравнивали удовольствие и страдание с добром и злом или же с тем, что их вызывает. Добром мы называем то, что способно вызвать или увеличить наше удовольствие либо уменьшить наше страдание или же обеспечить либо сохранность нам обладание каким-нибудь другим благом или же отсутствием какого-нибудь зла. Злом мы называем то, что способно причинить нам или увеличить какое-нибудь страдание, либо уменьшить какое-нибудь удовольствие, или же доставить нам какоенибудь неудовольствие, либо лишить нас какого-нибудь блага.

Мысль о страдании, которое может причинить нам присутствие или отсутствие какой-нибудь вещи, мы называем ненавистью. Наши любовь и ненависть к неодушевленным, бесчувственным предметам основываются обыкновенно на том удовольствии и страдании, которое мы получаем от пользования ими и применения их каким-нибудь образом к нашим чувствам. Ненависть и любовь к существам, способным испытывать счастье и несчастье, нередко есть неудовольствие или наслаждение, возникающее в нас самих при рассмотрении их жизни и счастья. Нужно отметить, что идеи любви и ненависти есть только состояния души по отношению к удовольствию и страданию вообще, независимо от того, чем они были вызваны в нас.

Какое бы благо ни предлагалось, если его отсутствие не вызывает неприятности и страдания, если человек чувствует себя без него спокойным и довольным, то нет никакого желания блага, никакого стремления приобрести его, нет ничего, кроме простого слабого желания.

Локк, рассуждая о страдании, определяет его в связке с удовольствием. Фактически философ выводит страдание и удовольствие в рефлексивное поле, показывая, что эти два проявления жизни человека тесно связаны с любым приятным и неприятным ощущением. Человеческие страсти свидетельствуют, что если ослабевает страданием, то начинает действовать удовольствие, а при уменьшении удовольствий начинает свое давление страдание. Все эти страсти присущи каждому человеку, ведь мы испытываем любовь, радость и надежду в течение жизни и думаем об удовольствии, а когда проявляется ненависть, страх и горе, то определяем это как страдание. Многие вещи, напрямую не связанные со страданием или удовольствием, но попавшие человеку в момент страстей, становятся связанными с удовольствием или страданием. Наша ненависть или наша любовь будет направлена и на этот объект. Но вот интересно, что объект, приносящий радость будет менее сильно ассоциироваться с удовольствием, чем объект, принесший несчастье будет привязан к страданию. И самое главное, этот объект будет постоянно нести страдание, эта привязка неизменна после первого проявления страдания. Локк подчеркивает, что всякое отсутствующее благо не причиняет страдания, равного своей действительной или признанной величине, в то время как всякое страдание возбуждает равное себе желание, ибо отсутствие блага не всегда есть страдание, каким бывает всегда наличие страдания.

Локк четко обозначает страдание как яркое проявление человеческих страстей и как противоположность по отношению к удовольствию. Философ не выходит за рамки гедонизма, но он усиливает фактор страдания в сравнении с удовольствием, объясняя это, прежде всего более сильным впечатлением горя и несчастья на человека. Страдание сильнее, т.к. мы боимся его. Эта мысль Локка уже постепенно ставит новые акценты в рамках этого варианта атрибутивной модели, появляется возможность рассматривать страдание как экзистенциальное переживание. И все же это только наметки будущих концепций. 
Все впечатления, с точки зрения Дэвида Юм, как внешние, так и внутренние, страсти, аффекты, ощущения, страдания и наслаждения - первоначально находятся на одном уровне и что, какие бы различия мы ни замечали между ними, все они по своему истинному характеру являются нам в качестве впечатлений, или восприятий. Наши страдания и наслаждения, наши страсти и аффекты, которым мы никогда не приписываем существования вне нашего восприятия, проявляются в нас с большей силой, чем впечатления фигуры и протяжения, цвета и звука, и оказываются столь же непроизвольными, как эти впечатления, которым мы приписываем постоянное бытие.

Забота о собственных интересах заставляет нас ощущать страдание при виде радости соперника и радость - при виде его страдания. Ненависть и любовь порождение страдательного принципа. Благожелательность есть первичное удовольствие, вызываемое тем удовольствием, которое испытывает любимый человек, и страдание, вызываемое его страданием; это соответствие впечатлений вызывает далее желание, чтобы этот человек испытывал удовольствие, и нежелание, чтобы он страдал. Ненависть же или презрение вызывается слабой степенью страдания или страданием, которому мы слабо сочувствуем.

Если нам предстоит получить от какого-нибудь объекта страдание или удовольствие, то мы чувствуем соответствующую эмоцию - отвращение или склонность - и стремимся либо избежать, либо достигнуть того, что может доставить нам это неудовольствие или удовольствие. Склонность или отвращение к какомунибудь объекту вызываются перспективой связанного с ним страдания или удовольствия, и эмоции эти распространяются на причины и действия данного объекта по мере того, как разум и опыт указывают нам последствие.

Во внутреннем мире человека основное противостояние удовольствия и страдания, при исчезновении этих мощных составляющих из нашего мыслительного процесса и чувственности, мы формируемся в большей мере в существа без желаний и без проявлений стремления к изменению своей жизни, появляется бездеятельность, аморфность существования. И удовольствие, и страдание притягивают движения нашего внутреннего мира, они провоцируют потребности чего-то и кого-то, формируют самые разные и крайние эмоции повседневности и экстремальности. Проявившиеся объекты, вызывающие удовольствие или страдание, получают импульс соотносящийся с нами лично или с другими людьми, они стремятся породить желание и отвращение, печаль и радость, но одновременно начинают вести к новым косвенным аффектам: гордости или униженности, любви или ненависти, которые в данном случае находятся в двойном отношении впечатлений и идей к страданию или удовольствию.

Юм особо подчеркивает силу страдания по отношению к удовольствию, отмечает созерцательный момент страдания, который имеет скорее положительный эффект нежели в аналогичной ситуации удовольствие. Юм четко выделяет страдание в ранг непостоянного явления жизни, тем самым, показав лишь силу этого внутреннего впечатления. Важно и то, что Локк и Юм говорят в основном об этических аспектах страдания и удовольствия, подтверждая убеждение, что гедонизм пытается определить правильность помыслов и поступков человека. Попытка эта не совсем удачная, т.к. нет главного - внутреннего осознания человеком себя и своего предназначения в этом мире. Страдание лишь обязательное проявление жизни и человек, пребывая в земном существовании, лишь думает о получении большего удовольствия.

Атрибутивность позиций и гедонистическая концепция Нового времени подтверждается и рассуждениями Иеремии Бентама, который считал, что в области морали основополагающими состояниями являются удовольствия и страдания. Человеческая природа - империя радостей и боли. Добиться удовольствия и избежать страдания - единственные мотивы действия, источник наших идей, наших суждений и наших определений. Моральное суждение становится суждением о счастье: благо - это удовольствие, порок - страдание. Действие человека является нравственным, если оно 
приводит к наибольшему удовольствию, и не является нравственным, если приносит больше страданий, чем удовольствия. Утилитарная концепция Бентама считает удовольствие высшей целью человечества, а освобождение большинства людей от страдания залогом счастливой жизни.

Бентам выявил некую гедоническую систему исчисления удовольствия и страдания. Согласно этой системе, удовольствие и страдание расчитываются по следующим параметрам: интенсивность; продолжительность; несомненность или сомнительность; отдаленность или близость; способность данного удовольствия приводить к дальнейшему удовольствию или способность данного страдания порождать дальнейшее страдание; способность страдания не порождать удовольствие или способность удовольствия не порождать страдание; масштаб, то есть число людей, которых это действие затрагивает.

Размеры определяемого таким образом страдания, которое проистекает из данного действия, затем сопоставляются с размерами удовольствия, проистекающего из того же самого действия, исходя из этого увеличивается страдание или удовольствие. Такое толкование противоречит многим религиозным представлениям о нравственной составляющей жизни человека. В частности, христиане считают, что долг стремиться к благу общества основывается не на Природе и не на удовольствии и страдании, а на Боге. Таким образом, Бентам сталкивается с проблемой заключенной в том, что Природа просто существует. Это «сущее», из которого нельзя вывести «должное». Бентам предстает здесь классическим гедонистом в рассмотрении страдания, который к тому жестко критикует многие религиозные постулаты.

В целом можно отметить, что в XVII - XVIII веках, а затем и в XIX веке гедонистический вариант рассмотрения страдания претерпевает некоторые изменения, связанные, прежде всего, с поиском ответов на жизненные вопросы вне религиозных и традиционных философских рамок. Общая тенденция этого периода в развитии философии страдания - рационалистические принципы в переплетении с этическими нормами религиозно-светского характера.

1. Антология мировой философии: в 4 т. - М.: Мысль, 1969. - 1587 с.

2. Гудинг, Д., Леннокс, Дж. Мировоззрение: человек в поисках истины и реальности. Т.2. Кн.2. Ярославль, 2004. - 480 с.

3. Юм, Д. Трактат о человеческой природе. - Минск, 1998. - 720 с.

4. Локк, Д. Сочинения в 3-х т. Т.1. Опыт о человеческом разумении. - М., 1985. - С. 183.

\section{Фетисова Е.Н. \\ К вопросу преподавания философии в современных условиях ФГБОУВО «Тихоокеанский государственный университет» (Россия, Хабаровск)}

doi: 10.18411/lj-05-2021-290

\section{Аннотация}

В статье рассматривается актуальная проблема современных российских вузов качество преподавания философии в свете кардинальных перемен в учебном процессе. Наиболее важными автор считает сокращение часов на лекционные и практические занятия, замена итогового контроля с экзамена на зачет, выстраивание диалога со студентами в дистанционном режиме, сокращение смежных философских дисциплин. Автор сравнивает два времени, когда кризис преподавания философии стал наиболее актуален: это распад СССР и наше время. Автор ставит вопрос о необходимости сохранения дисциплины «Философия» в российских вузах.

Ключевые слова. Преподавание философии, мировоззрение, качество, проблемы высшей школы 